GRASAS Y ACEITES 68 (1)

January-March 2017, e174

ISSN-L: 0017-3495

doi: http://dx.doi.org/10.3989/gya.0684161

\title{
Modification of olefinic double bonds of unsaturated fatty acids and other vegetable oil derivatives via epoxidation: A review
}

\author{
A.H. Noor Armylisas ${ }^{\mathrm{a},}$, M.F. Siti Hazirah ${ }^{\mathrm{b}}$, S.K. Yeong ${ }^{\mathrm{a}}$ and A.H. Hazimah ${ }^{\mathrm{a}}$ \\ ${ }^{a}$ Advanced Oleochemical Technology Division (AOTD), Malaysian Palm Oil Board (MPOB), 6, Persiaran Institusi, \\ Bandar Baru Bangi, 43000 Kajang, Selangor, Malaysia. \\ ${ }^{\mathrm{b}}$ Product Development and Advisory Services Division (PDAS), Malaysian Palm Oil Board (MPOB), 6, Persiaran Institusi, \\ Bandar Baru Bangi, 43000 Kajang, Selangor, Malaysia. \\ ${ }^{凶}$ Corresponding author: noor.armylisas@mpob.gov.my
}

Submitted: 30 June 2016; Accepted: 10 October 2016

SUMMARY: The highly strained ring in epoxides makes these compounds very versatile intermediates. Epoxidized vegetable oils are gaining a lot of attention as renewable and environmentally friendly feedstock with various industrial applications such as plasticizers, lubricant base oils, surfactants, etc. Numerous papers have been published on the development of the epoxidation methods and the number is still growing. This review reports the synthetic approaches and applications of epoxidized vegetable oils.

KEYWORDS: Epoxidation; Renewable feedstock; Unsaturated fatty acids; Vegetable Oils

RESUMEN: Modificación del doble enlace olefínico en ácidos grasos insaturados y en derivados de aceites vegetales via epoxidación: Revisión. La alta tensión del anillo en los epóxidos hace que estos compuestos intermediarios sean muy versátiles. Los aceites vegetales epoxidados están ganando mucha atención como materia prima renovable y respetuosa con el medio ambiente con diversas aplicaciones industriales, tales como plastificantes, aceites base para lubricantes, tensioactivos, etc. Por esta razón, se han publicado numerosos trabajos sobre el desarrollo de métodos de epoxidación y el número todavía es creciente. Esta revisión aporta información sobre enfoques sintéticos y aplicaciones de aceites vegetales epoxidados.

PALABRAS CLAVE: Aceites vegetales; Ácidos grasos insaturados; Epoxidación; Materia prima renovable

ORCID ID: Noor Armylisas AH http://orcid.org/0000-0001-7465-2368, Siti Hazirah MF http://orcid.org/0000-00018438-8441, Yeong SK http://orcid.org/0000-0003-0799-1751, Hazimah AH http://orcid.org/0000-0002-0365-9906

Citation/Cómo citar este artículo: Noor Armylisas AH, Siti Hazirah MF, Yeong SK, Hazimah AH. 2017. Modification of olefinic double bonds of unsaturated fatty acids and other vegetable oil derivatives via epoxidation: A review. Grasas Aceites 68, e174. http://dx.doi.org/10.3989/gya.0684161

Copyright: (C) 2017 CSIC. This is an open-access article distributed under the terms of the Creative Commons Attribution (CC-by) Spain 3.0 License. 


\section{INTRODUCTION}

The chemicals derived from oils and fats of vegetable and animal origin, or so-called oleochemicals, represent one of the cheapest and highly available sources of potential feedstock for replacing petroleum-derived products. This renewable raw material has also become an important feedstock for the chemical industry (Biermann et al., 2011). Efforts in finding potential sustainable and renewable sources have gained interests as the concern over environmental issues such as global warming and climate change are in the limelight. Vegetable oils predominantly contain triglycerides which can be hydrolyzed into fatty acids and glycerol (Scheme 1). Fatty acids contained a terminal carboxylic acid group with a carbon chain length ranging between 14 and 22 (saturated or unsaturated), which is characterized by the presence of double bond(s).

The global production of vegetable oils includes soybean, canola, palm, linseed, rapeseed, corn, cottonseed, peanut, sesame, and sunflower oil. Between 2002 and 2013, the total worldwide production of oils and fats increased by $57 \%$. In 2013, a total of 75.7 million tonnes of oils and fats were traded in the global market in which palm oil contributed to $58.1 \%$ of the total global edible oil exports followed by soybean oil $(12.7 \%)$, sunflower oil $(8.7 \%)$ and rapeseed oil $(5.4 \%)$ (Choo, 2014). More than $80 \%$ of the oil and fat production is used for food applications and only about $15 \%$ is used as oleochemical feedstock.

Basic oleochemicals are divided into four groups: fatty acids, the respective methyl esters, amines and alcohols. Glycerol is later added to the list (Richtler and Knaut, 1984), since it is produced in large amounts as a by-product in the formation of fatty acid methyl esters (biodiesel) due to the dramatic increase in biodiesel demands and as an important material with many uses (Gunstone and Hamilton, 2001).

Most of the classical, well-established chemical transformations of fatty acids and their derivatives involve reactions at the terminal carboxyl group, for instance esterification, amidation and amination to generate esters, amides and amines, respectively, as building blocks in the production of high value added products. Surfactant is one of the main oleochemical products that can be derived from the hydrogenation of fatty acid methyl ester derivatives to give fatty alcohols, an example of chemical modification on the carboxyl group (Scheme 1). The other reactive site that can be found in some of the fatty acids (see example of palm oil fatty acids in Figure 1) of vegetable oils is the olefinic double bond. About $90 \%$ of the oleochemical reactions occur at the carboxylic group and only 10\% represents reactions involving the alkyl chain of fatty acids (Richtler and Knaut, 1984).

\section{SYNTHETIC APPROACHES}

Numerous synthetic methods to access epoxide have been explored, such as epoxidation with aldehydes and molecular oxygen, dioxiranes, $\mathrm{H}_{2} \mathrm{O}_{2}$ /tungsten heteropolyacids, and $\mathrm{H}_{2} \mathrm{O}_{2}$ /methyl trioxorhenium as well as the Halcon process. However, none of these methods can be scaled up for industrial applications.

The oxygen transfer to the double bond can be achieved via two pathways: a single oxygen donor

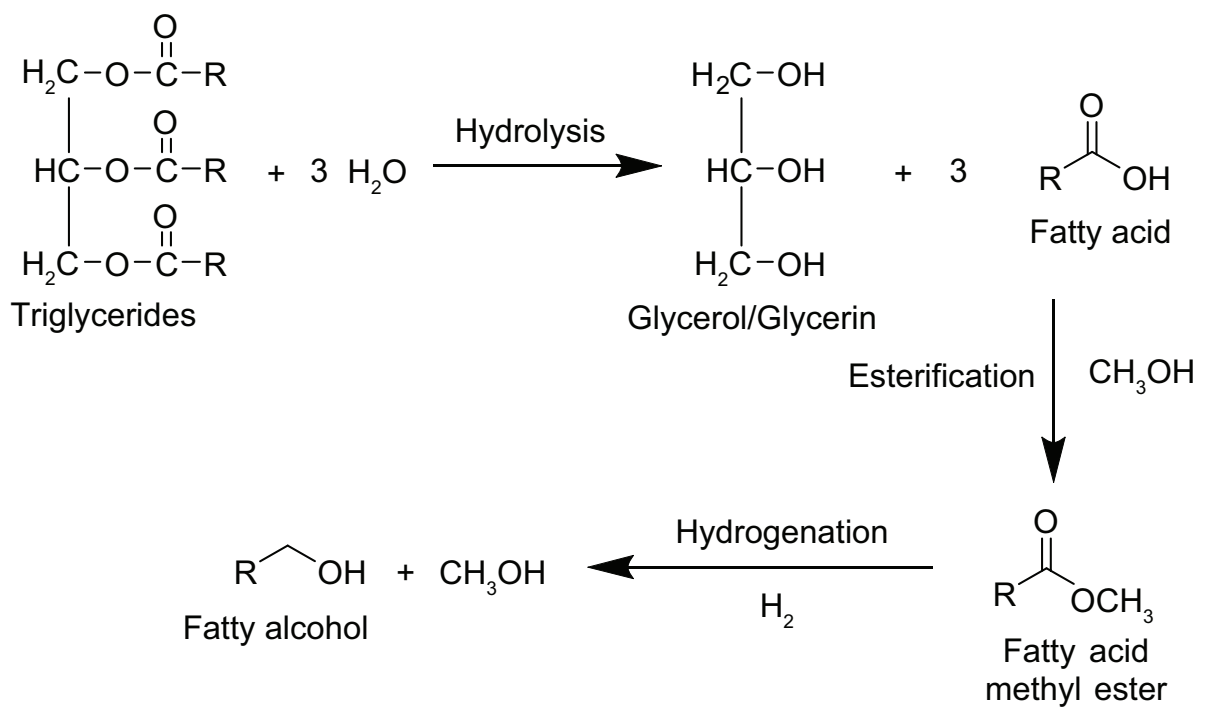

SCHEME 1. Basic oleochemical transformations to obtain fatty alcohol from oil. 
(for example, $\mathrm{H}_{2} \mathrm{O}_{2}$, organic hydroperoxides, peracids) and radical epoxidation (for example, using molecular oxygen, $\mathrm{O}_{2}$ with different catalysts). The stereochemistry of the epoxides obtained depends on the route in which the reaction occurs. For instance, the epoxidation of methyl oleate via non-radical epoxidation will form cis-epoxides. On the other hand, both cis- and trans-epoxides will be formed following the radical epoxidation route (Köckritz and Martin, 2008).

Reaction temperature, molar ratio (concentration of oxygen donor, oxygen carrier and ethylenic unsaturation), catalysts type (homogeneous or heterogeneous) and catalyst loading are some of the variables taken into account in the studies of epoxidation of the unsaturated fatty acids (Ni and Salimon, 2012). Goud et al. (2007) reported that the catalytic epoxidation rate increased with the increment of the stirring speed under triphasic conditions before it levelled off at ca. $1500 \mathrm{rev} / \mathrm{min}$. This subtopic reviews some of common methods for epoxidation.

\subsection{Hypochlorination}

Hypochlorination of the olefinic acid followed by dehydrohalogention, is one of the earliest preparations of the epoxy acids via chemical means (Scheme 2) (Nicolet and Poulter, 1930). This method, however, is not suitable for large-scale experiments as the dehydrohalogenation step rarely exceeds $50 \%$ yield, in contrast with small scale experiments affording an excellent yield of epoxides (Swern, 1955).

\subsection{Prilezhaev reactions}

In industrial processes, the Prilezhaev reaction, i.e. the epoxidation reaction using peracids as the oxygen transfer reagent to the olefin, is the traditional, most commonly used method for the epoxidation of fatty acids and triacylglycerols (Köckritz and Martin, 2008). Two common oxidants employed in the industry are performic acid and peracetic acid, generated in-situ using hydrogen peroxide as the oxygen donor and a carboxylic acid such as formic acid ( $\mathrm{Ni}$ and Salimon, 2012) or acetic acid. While the use of formic acid can be carried out with no catalyst requirement (Ni and Salimon, 2012), acetic acid requires an acid catalyst, either a strong inorganic acid (Dinda et al., 2008), such as $\mathrm{HCl}$,

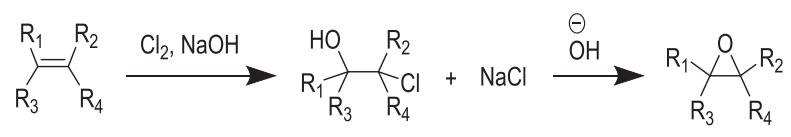

Scheme 2. Hypochlorination of olefin (Swern, 1955).
$\mathrm{HNO}_{3}, \mathrm{H}_{3} \mathrm{PO}_{4}$ and the most widely used is $\mathrm{H}_{2} \mathrm{SO}_{4}$, or acidic ion exchange resins (AIER) (Cooney et al., 2011; Mungroo et al., 2008). The mechanism for this reaction can be seen in Scheme 3. Despite having a higher rate of epoxide formation when formic acid is employed (Dinda et al., 2008), acetic acid is found to be a better choice as $10 \%$ higher conversion of ethylenic unsaturation to epoxides is observed compared to formic acid (Mungroo et al., 2008).

When epoxidation is carried out using hydrogen peroxide and the unsaturated fatty acid without the presence of organic peracid, no reaction is observed, as the peracid is essential for transfering the active oxygen from the aqueous to the oil phase (Nowak et al., 2003). The use of the strong mineral acids, however, has a few drawbacks including non-selectivity and low epoxide content in the final product as the highly strained epoxide ring is susceptible to ring-open under acidic conditions, giving rise to a number of side products such as diols, hydroxyl esters, estolides and other dimer formation (Figure 2) (Saurabh et al., 2011). The handling of the peracid on a large scale is very hazardous due to its instability and explosive property in high concentrations (Cooney et al., 2011). The use of mineral acids also resulted in several problems such as equipment corrosion and environmental issues, and the acid must be neutralized and removed from the end product (Cai and Wang, 2011).

Conversion as high as $98 \%$ was reported for the methyl ester of palm fatty acid distillate (PFAD-ME) producing a respective epoxide compound using a molar ratio of 1:1:4 (PFAD-ME:formic acid: $\mathrm{H}_{2} \mathrm{O}_{2}$ ) at $50{ }^{\circ} \mathrm{C}$ (Lee et al., 2009).

Thus, over the last ten years, many studies have been reported on homogeneous and heterogeneous catalytic epoxidation, from the enzyme- to metal-catalyzed reaction of vegetable oils with different oxidants considering the advantages offered by the modified fatty acids derived from vegetable oils.

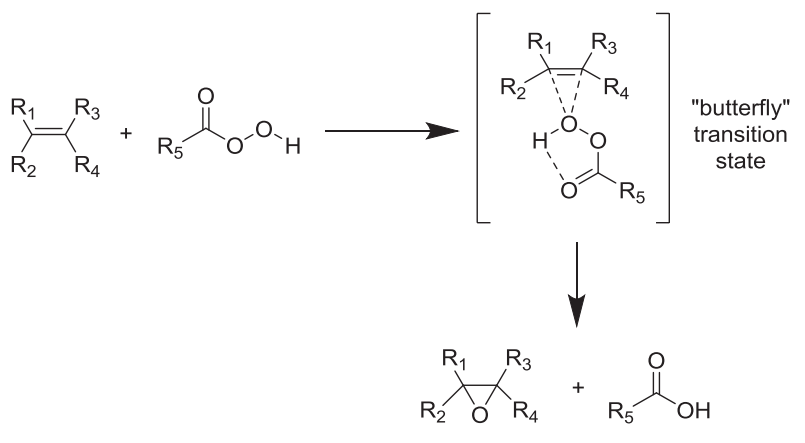

SCHEME 3. Mechanism for epoxide formation mediated by peracids. 


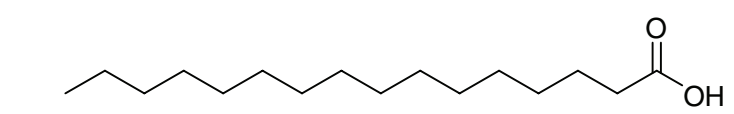

Palmitic acid (C16:0), $44-45 \%$
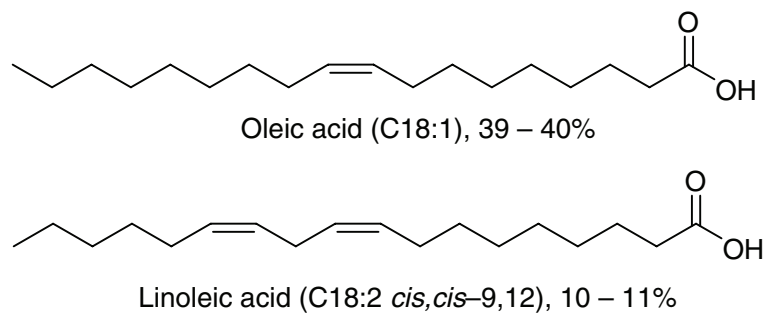<smiles>CC/C=C/C/C=C/C/C=C/CCCCCCCC(=O)O</smiles>

Linolenic acid (C18:3 cis, cis, cis-9,12,15), trace mount

FIgURE 1. Fatty acid composition in palm oil ("About Palm Oil,” 2011).

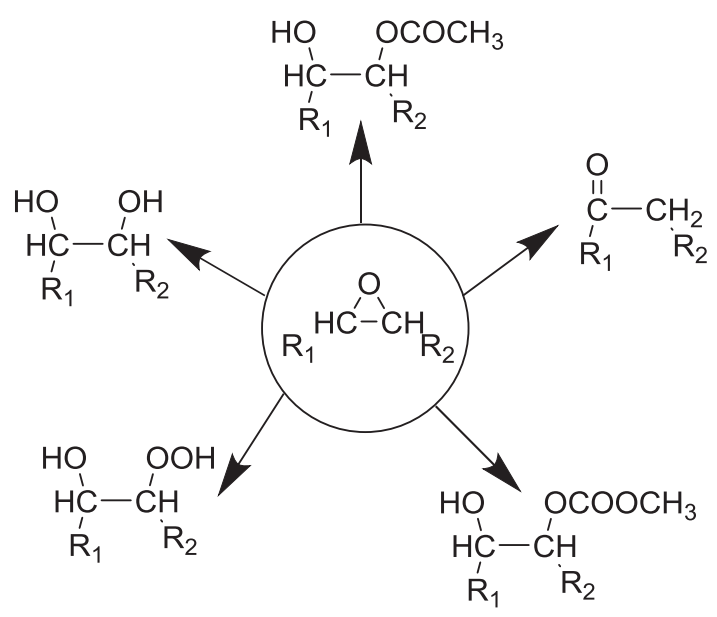

Figure 2. Products of side reactions from epoxide

\subsection{Acidic ionic exchange resins (AIER)}

Acidic ionic exchange resin was then introduced as a heterogeneous catalyst replacing the inorganic acid catalyst with improved yield and/or selectivity. Mungroo et al. (2008) and Dinda et al. (2008) studied the catalytic activity of AIER on the epoxidation of canola and cottonseed oil, respectively, using peroxyacetic acid as the oxidant with good oxirane conversion, up to $65 \%$, and selectivity as high as 90\%. Borugadda and Goud (2014) reported the epoxidation of castor oil fatty acid methyl esters using Amberlite IR-120(H) for the synthesis of biolubricant base stock. This catalyst, however, has some disadvantages which limit its application for large scale production, such as high mass transfer resistance, long reaction time, high cost and nonuniform acid sites (Cai and Wang, 2011).
In 2011, Cai and co-worker (Cai et al, 2011) brought into light the use of $\mathrm{SO}_{3} \mathrm{H}$-functional Brønsted acidic ionic liquid as catalyst for the epoxidation of fatty acid methyl esters giving as high as $84.4 \%$ oxirane conversion (Cai and Wang, 2011). Cai suggested that this "task-specific ionic liquid" (TSIL) catalyst shows great potential as a replacement of conventional homogeneous/heterogeneous acid catalysts with properties like flexibility, nonvolatility, non-corrosive and immiscibility in many organic solvents and has been reported to be applied in other organic reactions, such as esterification, alcoholysis, Claisen-Schmidt condensation, nitration and hydrolyzation.

\subsection{Molecular oxygen and aldehyde}

Molecular oxygen $\left(\mathrm{O}_{2}\right)$ can act as oxygen donor via the radical epoxidation pathway. The presence of a metal catalyst is said to affect the initiation, rate of reaction and selectivity to epoxides in competition with allylic oxidation. The aldehyde will be co-oxidized into carboxylic acid along with epoxide formation.

The metal complex catalyst can be recycled up to ten times as reported in the Ru-catalyzed epoxidation of methyl oleate in a perfluorinated solvent (Klement et al., 1997; Ragagnin and Knochel, 2004).

\subsection{Organic hydroperoxides}

Tert-butyl hydroperoxide (TBHP), ethylbenzene hydroperoxide and cumyl hydroperoxide (CHP) are examples of organic hydroperoxides that have been used as oxidants in the presence of metal catalysts, such as Mo, Ti, and Ru.

The industrial production of propylene oxide mediated by TBHP and ethylbenzene hydroperoxide was first developed by The Halcon Corp. and Atlantic Richfield Oil Corp. (later ARCO) in 1970s using isobutane and ethylbenzene, respectively. Interestingly, this method produced $t$-butanol (starting material of methyl tert-butyl ether, MTBE) and $\alpha$-methylbenzyl alcohol (starting material of styrene) as co-product (Scheme 4).

Titanium-derived catalysts are used both as homogeneous and heterogeneous catalysts. The latter are found to be more efficient for the epoxidation reaction. The use of a titanium tartrate complex as a homogeneous catalyst in the Sharpless-Katsuki epoxidation is one of the well-known examples of asymmetric epoxidation ( $\mathrm{Li}$ and Wang, 1997). Omar et al. (2003) reported the application of this reaction on $(13 S)$-hydroxy-9Z, $11 E$-octadecadienoate (13S-HODE) giving $76 \%$ of diastereomeric excess.

Guidotti et al. (2006) reported high epoxide and diepoxide yields from the epoxidation of methyl ester derivatives of fatty acids from different vegetable oils, obtained using TBHP as oxidant and 


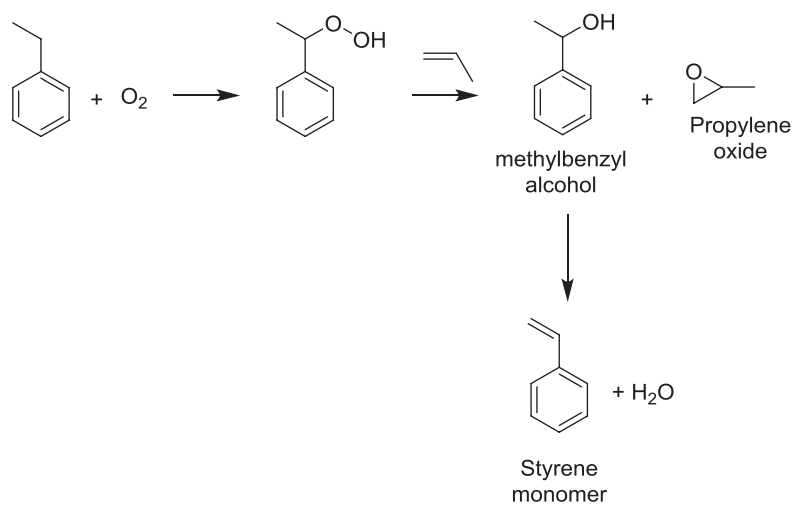

SCHEME 4. Halcon process mediated by ethylbenzene hydroperoxide.

Ti-MCM-41 (ordered mesoporous titanium-grafted silica). Catalytic activity is highly dependent on textural properties as the catalytic reaction was reported to occur at the external surface area of these materials. Superior catalytic activity of the well-structured titanosilicates compared to non-ordered $\mathrm{Ti}_{-} \mathrm{SiO}_{2}$ has been proven in several reports. This method offers several advantages, including acid-free conditions, easy removal of catalyst by filtration and low oxidant excess.

However, simple amorphous $\mathrm{Ti}^{-} \mathrm{SiO}_{2}$ is shown to be a good alternative to titanosilicates (especially for much more expensive Ti-MCM-41 material) as a comparable yield of up to $60 \%$ epoxidised methyl oleate can be obtained with good selectivities $(>90 \%)$. Rios et al. (2005) reported that catalyst structure does not play any important role in catalytic reactivity.

The use of organic hydroperoxides is not limited to metal catalysts. In 2001, Piazza et al. reported the use of TBHP in enzymatic epoxidation.

\subsection{Enzymatic epoxidation}

The biocatalyzed reaction is more environmental friendly and it is more selective. This method is considerably favored as it suppresses undesirable ring opening of the epoxide (Biermann et al., 2000), and can lead to high selectivity. On top of that, the stability and separation of enzymes are improved by the immobilization of the enzymes (Köckritz and Martin, 2008). Immobilized Candida antarctica lipase B is one of the enzymes used in most of the chemo-enzymatic epoxidation reactions of several vegetable oils i.e. soybean, rapeseed, linseed and sunflower oil. The lipase enzyme is reusable, selective and exhibits excellent stability and catalytic reactivity with a conversion rate of over $90 \%$.

The earliest report of enzymatic epoxidation was made in the early 1930 s using cytochrome P450 monooxygenase (CYP) on arachidonic acid, oleic acid, linoleic acid, $\alpha$-linoleic acid, 5, 8, 11-eicosatrienoic acid, 5, 8, 11, 15, 17-eicosapentaenoic acid and docosahexaenoic acid producing the corresponding mono-epoxides (Oliw, 1994; Zhang et al., 2014).

The first chemo-enzymatic epoxidation was carried out in 1990 (Björkling et al., 1990). Studies made by Vlček and Petrović (2006) revealed that in the epoxidation of soybean oil, the rate of reaction was dependent on the concentration of the lipase enzyme. Enzyme sensitivity towards temperature was reported by Sun et al. (2011) in the epoxidation of Sapindus mukorossi seed oil (SMSO) using $\mathrm{H}_{2} \mathrm{O}_{2}$ as the oxidant; the reaction temperature and enzyme load had significant effects on epoxidation while reaction time and substrate ratio were less significant. Sun also suggested the epoxidation of SMSO is enhanced with the use of stearic acid as active oxygen carrier (Sun et al., 2011).

Orellana-Coca et al. (2007) investigated the effect of the reaction variables on the lipase-mediated epoxidation of linoleic acid. This study revealed that the excess amount of $\mathrm{H}_{2} \mathrm{O}_{2}$ with respect to the number of double bonds present in the fatty acid is crucial to cut short the reaction time to compensate for $\mathrm{H}_{2} \mathrm{O}_{2}$ decomposition for reactions above $50{ }^{\circ} \mathrm{C}$ and to increase the reaction rate $\left(\mathrm{H}_{2} \mathrm{O}_{2}\right.$ concentration between $10-50 \% \mathrm{wt}$ ) at the expense of enzyme inactivation.

The use of oat seed (Avena sativa) peroxygenase immobilized onto a hydrophobic support was also reported in the enzymatic epoxidation of sodium oleate. $80 \%$ conversion to epoxide was obtained using $t$-butyl hydroperoxide (TBHP) as the oxidant at $65^{\circ} \mathrm{C}$ after 24 hours. This study also revealed $\mathrm{pH}$ and temperature dependence of this stereospecific reaction (Piazza et al., 2001). Later, they reported the improvement of the epoxidation of vegetable oil amides from linseed oil in hexane with the addition of a small amount of isopropyl ether and buffered water containing Tween 20 using TBHP and cumene hydroperoxide as oxidants (Piazza and Foglia, 2005).

The effect of different epoxidation methods has been investigated by Saithai et al. (2013) employing two enzymes: Novozyme ${ }^{\circledR} 435$ (CALB) and a homemade lipase/acyltransferase (CpLIP2), and in-situ chemical epoxidation using $\mathrm{H}_{2} \mathrm{O}_{2}$ and formic acid.

A recent publication of enzymatic-mediated epoxidation was reported by Grausem et al. (2014). They reported on the epoxidation of linoleic acid (C18:2) by CYP77A19, one of the two cDNA clones of new cytochrome P450s from potato tubers (Solanum tuberosum).

In general, low stability of the enzyme under certain reaction conditions limits the potential of this method compared to chemical treatment due to the sensitivity of the enzyme to the concentration of hydrogen peroxide. The enzyme has been reported to be stable at a temperature of up to $50^{\circ} \mathrm{C}$. Nevertheless, this reaction condition is not favorable 


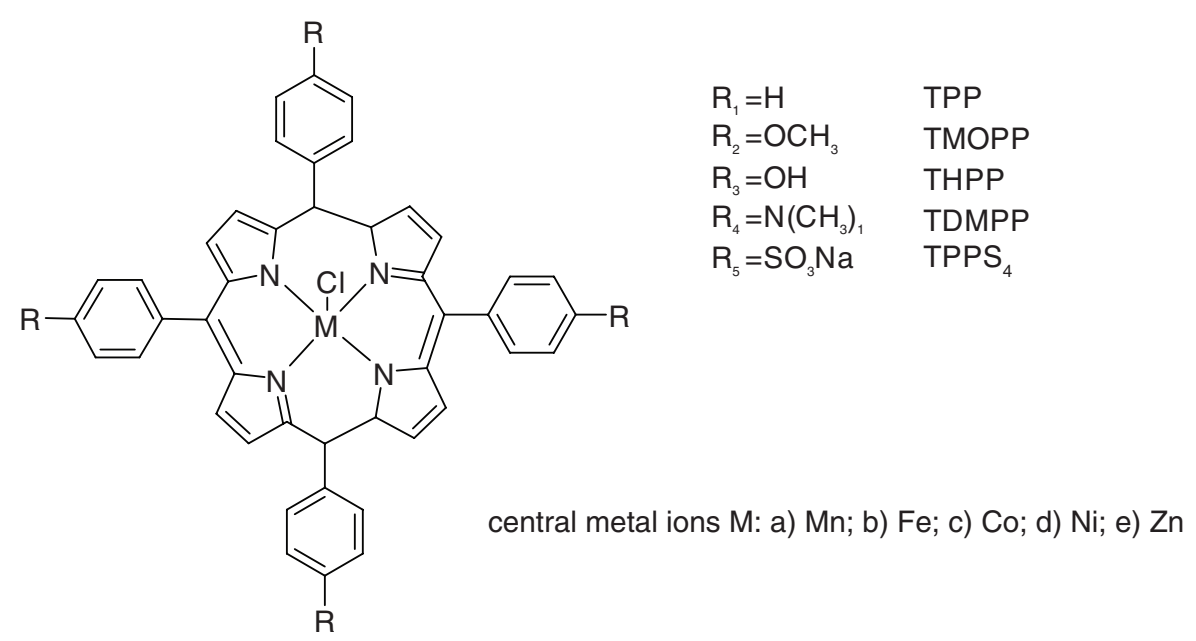

FIGURE 3. Structures of metallophyrin developed by Zhang for catalytic epoxidation (Zhang et al., 2014).

due to the decomposition of $\mathrm{H}_{2} \mathrm{O}_{2}$ and possible reduced catalytic activity of the enzyme.

\subsection{Metalloporphyrin}

Metalloporphyrins are a combination of a porphyrin and metal such as heme. These compounds have been shown to selectively catalyze various reactions, i.e. oxygenation, oxidation, oxidative chlorination and dismutation.

A recent work concerning the catalytic epoxidation of fatty acid methyl esters (FAMEs) was reported by Zhang et al. (2014) using tetraphenylporphyrins modified with variable metals (such as $\mathrm{Mn}, \mathrm{Fe}, \mathrm{Co}, \mathrm{Ni}, \mathrm{Zn}$ ) and electron-donating substituents (Figure 3).

\subsection{Dioxiranes}

Dioxiranes have been shown to be one of the most versatile reagents for epoxidation as they transfer an oxygen atom efficiently to a variety of organic substrates (Curci et al., 1984). The preparation can be either in an isolated solution or in-situ (Scheme 5) (Frohn et al., 1998). Dioxiranes are powerful and selective oxidants for electron-rich alkenes, whereas electron-poor alkenes such as $\alpha, \beta$-unsaturated acids, esters and ketones (Adam et al., 1990; Armstrong and Ley, 1990; Messeguer et al., 1991), and $\beta$-oxo enol ethers (Adam and Hadjiarapoglou, 1990) will require elevated temperatures (up to $30{ }^{\circ} \mathrm{C}$ ), extended reaction times (up to 2 days), and an excess of dioxirane (up to 3 equiv) for complete conversion. Numerous synthetically useful transformations of a wide variety of organic substrates have been carried out employing dioxiranes.

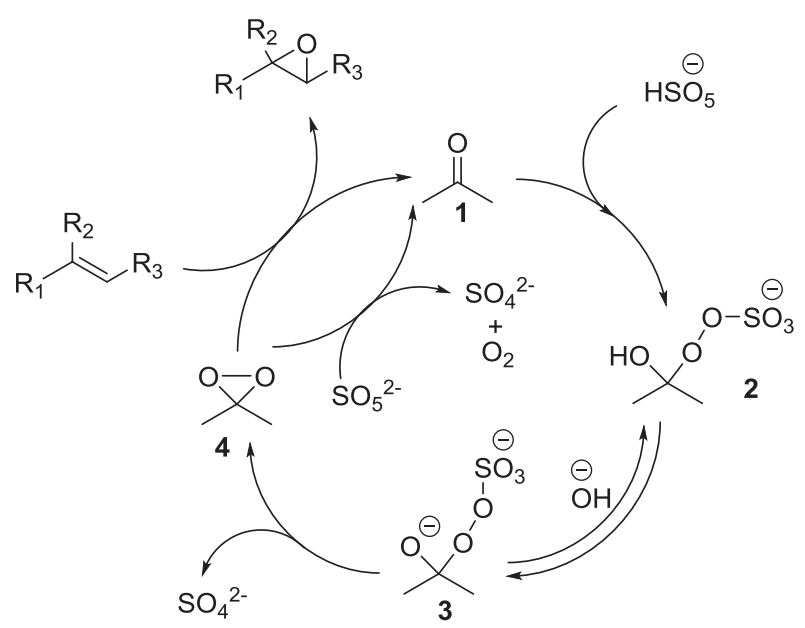

SCHEME 5. Catalytic cycle of DMDO as oxidant (Frohn et al., 1998).

Dimethyldioxirane (DMDO) is the simplest form of dioxirane. This reagent is not commercially available due to instability during transport and storage but it can be prepared by reacting acetone and the triple salt Oxone ${ }^{\circledR}\left(2 \mathrm{KHSO}_{5} \cdot \mathrm{KHSO}_{4} \cdot \mathrm{K}_{2} \mathrm{SO}_{4}\right)$ in the laboratory, both on small and large scales (Adam et al., 1987).

Adam et al. (1989) suggested that $\mathrm{pH}$ control between 7.0 and 7.5 by means of phosphate or bicarbonate buffer is essential for in-situ generation of dioxirane as low $\mathrm{pH}$ will suppress the critical deprotonation step (from 2 to 3 , Scheme 5). In addition, high $\mathrm{pH}$ leading to the destruction of dioxirane by oxygen transfer competition from the dioxirane to the substrate or $\mathrm{SO}_{4}^{2-}$, and autodecomposition 
of Oxone ${ }^{\circledR}$ is a concern. Nevertheless, Frohn et al. (1998) reported that some of the chiral ketones studied were highly $\mathrm{pH}$ dependent, and the reactions at higher $\mathrm{pH}$ are more efficient. He suggested that the formation of oxy-anion 3 (Scheme 5) is preferred at a high $\mathrm{pH}$, which led to efficient formation of DMDO.

There have been previous studies on the epoxidation of vegetable oil mediated by ethylmethyldioxirane (EMDO), an analogue of the dioxiranes. In 2007, Akintayo reported complete conversion of the double bond in the epoxidation of Plukenetia conophora oil (Akintayo, 2007). Epoxidation of methyl oleate and methyl ricinoleate were reported by Sonnet affording the corresponding epoxides in excellent yield (Sonnet and Foglia, 1996). Both of these reactions were accomplished under biphasic conditions employing 2-butanone as the solvent as reported by Curci et al. (1980).

\section{APPLICATIONS OF EPOXYGENATED FATTY ACIDS AND THEIR DERIVATIVES}

Generally, further application of the oils as oleochemicals are determined by the fatty acid composition (Hill, 2000). For example, coconut oil and palm kernel oil are suitable raw materials for further processing as surfactant as these fatty acids mainly comprise of $\mathrm{C} 12$ and $\mathrm{C} 14$. The oils and fats containing long-chain fatty acids (C18 and above), such as palm, soybean, rapeseed and sunflower oil (Table 1) as well as animal fats like tallow, are used for application in the polymer industry and lubricants (Kreienfeld and Stoll, 1997). Modification of basic oleochemicals gives rise to many oleochemical derivatives for numerous applications in industry.

A wide range of chemicals can be derived from epoxidized fatty acids, for example, polyols, glycol, carbonyl compounds, lubricants, plasticizers for polymer, etc. (Saurabh et al., 2011).

\subsection{Stabilizer/Plasticizer for rubber and PVC}

One of the primary markets for epoxidized vegetable oils (mainly soybean) is as plasticizers and hydrogen chloride acceptors for use in plastic materials, especially polyvinyl chloride (PVC). As PVC exposed to heat and/or light, the $\mathrm{HCl}$ evolved which may cause the development of undesirable color and rapid deterioration of the polymer (Greenspan and Gall, 1953; Swern, 1955). Plasticizers are additives integrated into rigid polymeric material to improve their flexibility, workability, and distensibility, thereby increasing the plastic utility in numerous applications.

A recent study by Kandula et al. (2014) showed that fatty acid methyl ester ketals derived from soybean oil can be synthesized via the epoxide as intermediates. The synthesized soy ketal compounded with PVC exhibited better thickening and aging behaviors as compared to petroleum-based plasticizers.

\subsection{Surface coatings}

Corrosion is a common problem faced in our daily lives. The idea of using renewable resources in coating technology is crucial as an effort to reduce our reliance on non-renewable petroleumbased products (Alam et al., 2014). Furthermore, the development of coating materials from renewable sources such as vegetable oil can provide low cost in the large scale production due to availability. Naturally occurring epoxidized oil (such as Euphorbia lagascae and Vernonia galamensis) is uncommon. However, in the case of palm oil, the active functional groups introduced can play

TABLE 1. C14 - C24 fatty acid composition of some major vegetable oils (Saurabh et al., 2011)

\begin{tabular}{|c|c|c|c|c|c|c|c|c|c|c|}
\hline \multirow[b]{2}{*}{ Vegetable Oil } & \multicolumn{10}{|c|}{ Fatty acid composition, $w t^{0} \%^{a}$} \\
\hline & 14:0 & 16:0 & 18:0 & 20:0 & 22:0 & 24:0 & 18:1 & 22:1 & 18:2 & $18: 3$ \\
\hline Corn & - & 12 & 2 & $\operatorname{Tr}$ & - & - & 25 & - & 6 & $\operatorname{Tr}$ \\
\hline Cottonseed & - & 28 & 1 & - & - & - & 13 & - & 58 & 0 \\
\hline Linseed & - & 5 & 2 & - & - & - & 20 & - & 18 & 55 \\
\hline $\begin{array}{l}\text { Palm (Rupilius and } \\
\text { Ahmad, 2007) }\end{array}$ & 2 & 42 & 5 & - & - & - & 41 & - & 10 & - \\
\hline Peanut & - & 11 & 2 & 1 & 2 & 1 & 48 & - & 32 & 1 \\
\hline Rapseed & - & 3 & 1 & - & - & - & 64 & - & 22 & 8 \\
\hline Sesame & - & 13 & 4 & - & - & - & 53 & - & 30 & - \\
\hline Soybean & - & 12 & 3 & - & - & - & 23 & - & 55 & 6 \\
\hline Sunflower & - & 6 & 3 & - & - & - & 17 & - & 74 & - \\
\hline
\end{tabular}

${ }^{\mathrm{a}} \mathrm{Tr}=$ traces. 
an important role in the downstream chemical industry as well as its applications. The epoxides of methyl ester of oleic acid have been reported to have good corrosion inhibitor properties and polymeric binders (Feldmann and Schäfer, 2001) which are important properties as coating materials attributed to the long hydrophobic chains of the fatty acids which also contribute to the high flexibility of the substance.

Dihydroxystearic acid which is derived from the hydroxylation of epoxidized palm fatty acid has shown to exhibit rust inhibition properties evaluated using stainless steel rod in bis (2-ethylhexyl) sebacate and tris (2-ethylhexyl) phosphate (Rahman and Sadi, 1998).

\subsection{Lubricant}

Lubricant is a substance employed to reduce wear or tear of one or both surfaces in mutual contact and moving in relation to each other. In general, vegetable oils possess most of the necessary lubricity properties such as good contact lubrication, high viscosity index (lowest changes in viscosity with temperature), high flash point and low volatility. Above all, the presence of a high degree of unsaturation in vegetable oils led to low thermal and oxidative stability, which can be improved by epoxidation (Akintayo, 2007).

The evaluation of palm kernel oil's (PKO) properties as lubricant has been reported previously. The properties of PKO were compared with heavy duty oil (SAE 40) and light duty oil (SAE 30) and it was shown that PKO is a promising base oil for the production of value-added lubricating products with comparable properties that meet SAE specifications (Musa, 2009). Nevertheless, there are still limitations on some properties that requires modification such as poor low-temperature properties, susceptibility to oxidative degradation and tendency to undergo hydrolysis under acidic conditions (Campanella et al., 2010). Epoxidized castor oil was showed to possess enhanced properties of lubricity like higher density, kinematic viscosity and pour point. This is probably due to the stronger interaction between the molecules of the epoxides (Borugadda and Goud, 2014).

The study of the production of polyols with branched ether and ester compounds, with epoxidized vegetable oils as the intermediates has been carried out for the improvement of their properties. The epoxides will then be subjected to ring-opening reaction under acidic conditions to produce alcohols which will then be subjected to esterification reactions (Adhvaryu et al., 2002).

Moser et al. (2007) reported improved oxidative stability and fluidity at low temperatures via esterification of alkyl 9,10-epoxyoctadecanoates using propionic and octanoic acids under catalyst- and solvent-free environments.

\subsection{Polyol and polyurethane production}

The reaction of the epoxygenated fatty acids with low-molecular-weight mono- or polyfunctional alcohols or acids via the ring-opening of the oxirane afforded polyols (Hazimah et al., 2011) that can be used in a polyurethane system, adhesives and casting resins (Norhayati et al., 2013). Polyols can also serve as raw material in the production of palm-based flexible polyurethane foams (Shaari et al., 2006) to manufacture some daily products such as carpet underlay, sandwich panels and headrests (Hazimah, 2012). Polyols can also be used in a wide range of coating processes from thin decorative or protective coating to industrial flooring applications due to their relatively low viscosity and compatibility with methylene di (phenylisocyanate) (MDI). A study on the alcoholysis of epoxidized palm olein catalyzed by K10 Montmorillonite produced palm-based polyol which can be used as a component in coating applications (Norhayati et al., 2013).

Preparation of low viscosity and light-colored fatty acid-based polyols can be carried out in a three-step reaction, depending on several parameters at each step such as temperature, pressure, amount of catalyst used, molar ratio of reactant, and reaction time. Catalyst loading was reported as crucial factor to be controlled to produce light-colored polyol in the first step (Hoong et al., 2008).

A patent was filed for the conversion of used frying oils into polyol via epoxidation as one of the intermediates followed by reaction with diisocyanate to afford the corresponding polyurethane product. The epoxidation was carried out using peroxyacetic acid or performic acid at $65-70{ }^{\circ} \mathrm{C}$ (Shaari et al., 2006).

Self-levelling polyurethane or epoxy/polyurethane multilayer systems are widely used in the flooring industry because of good chemical and mechanical properties such as minimal shrinkage, high mechanical strength and durability, and the reasonable cost of installation offered by these materials. Apart from that, they can also be used to bind porous filler materials and rubber particles to produce composites for sport tracks and playing fields (Höfer, 1999).

\subsection{Material for the synthesis of radiation curable resins}

The epoxygenated palm olein acrylate derived from the respective epoxide was studied for use in the synthesis of radiation curable resins 


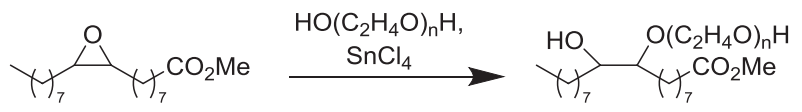

SCHEME 6. Ring opening of epoxidized methyl oleate (Dierker and Schäfer, 2010).

(Mohd Nor et al., 1992). The presence of the "high strain energy" rings on the fatty acid chains promote cross-linking when the epoxy resin is cured. The higher the number of epoxy rings that are opened by the process, the more cross linking can occur, and the higher the quality of the resulting plastic (Goud et al., 2007).

\subsection{Surfactants}

Most of commercial ionic and non-ionic surfactants are derived from $\mathrm{C} 12$ and $\mathrm{C} 14$ fatty acids which are abundant in PKO. Fatty acids with longer carbon chains are barely used due to their hydrophobic property and less suitable for micelle formation. As for palm oil that contains longer chain fatty acids, the modification of the fatty acids has been carried out to increase the polarity of the fatty acids. Epoxide can serve as an intermediate to attach the polar groups to internal positions of the fatty acids (Dierker and Schäfer, 2010). Internal diols can be obtained by acid-catalyzed ring opening of the epoxidized fatty acids or by dihydroxylation in the presence of osmium tetroxide as catalyst. Conversion of methyl oleate into methyl vic-oligoethyleneglycol hydroxy oleate was carried out in the presence of tin tetrachloride (Scheme 6).

The surfactants with tensidic properties synthesized by the modification of long chain fatty acids were shown to be comparable or with better properties than those of commercial surfactants of C12 and C14 fatty acids (Dierker and Schäfer, 2010).

Ring-opening of epoxidized methyl oleate occurred when reacted with bifunctional levulinic acid to form cyclic ketals, by controlling the temperature and acid concentration, led to potential new surfactants derived from oleochemicals (Doll and Erhan, 2008).

\subsection{Pharmaceutical}

In a pharmacological study, the epoxidation of arachidonic acid catalyzed by cytochrome P450 (CYP) epoxygenase generated the corresponding epoxygenated fatty acid, the epoxyeicosatrienoic acid - an important mediator involved in regulating various biological processes including inflammation, pain and angiogenesis (Zhang et al., 2014).

\section{FUTURE RESEARCH AND DEVELOPMENT IN EPOXIDATION/EPOXIDIZED OIL - THE WAY FORWARD}

Due to the vast applications, and environmentally friendly properties of the epoxidized vegetable oils, the development of synthetic methods is highly anticipated in addition to the increasing awareness for caring for the environment. Several conditions must be taken into account in the continuous research on epoxide synthesis: i) presence of acid (as co-reagent or generated during the reaction) lower epoxide yield and; ii) cost of by-product removal (Piazza, 1999).

Mild conditions in the epoxidation of fatty acids mediated by dioxiranes have made this method one of the most attractive approaches to be developed especially for larger scale reactions. To our knowledge, the effect of the stereochemistry of epoxidized vegetable oils on their properties has never been studied previously.

\section{CONCLUSIONS}

The studies for developing synthetic methods for the epoxidation of unsaturated fatty acids are important to afford high oxirane content and selectivity. As for industrial scale, the reaction conditions are significant in order to minimize operation costs, and avoid side reactions. The in-situ formation of peracid is still the most convenient method to date in large scale production.

Various applications of epoxidized vegetable oils have made this product a valuable intermediate or end-product due to the versatility of the threemembered ring epoxy in chemical reactions, and the green properties of the materials such as no toxicity and biodegradability.

\section{ACKNOWLEDGMENTS}

The authors would like to thank the Malaysian Palm Oil Board (MPOB) for their support in producing this review paper. Our gratitude is also extended to Puan Rosnah Ismail and Prof. Kamaruzaman Jusoff, Senior Research Fellows of MPOB.

\section{REFERENCES}

Adam W, Chan Y, Cremer D, Gauss J, Scheutzow D, Schindler M. 1987. Spectral and chemical properties of dimethyldioxirane as determined by experiment and ab initio calculations. J. Org. Chem. 52, 2800-2803. http://dx.doi. org/10.1021/jo00389a029

Adam W, Curci R, Edwards JO. 1989. Dioxiranes: A new class of powerful oxidants. Acc. Chem. Res. 22, 205-211.

Adam W, Hadjiarapoglou L. 1990. Dimethyldioxirane epoxidation of $\beta$-oxo enol ethers. Chem. Ber. 123, 2077-2079. http://dx.doi.org/10.1002/cber.19901231022

Adam W, Hadjiarapoglou L, Nestler B. 1990. Dimethyldioxirane epoxidation of unsaturated ketones, acids and esters. 
Tetrahedron Lett. 31, 331-334. http://dx.doi.org/10.1016/ S0040-4039(00)94547-7

Adhvaryu A, Erhan SZ, Perez JM. 2002. Wax appearance temperatures of vegetable oils determined by differential scanning calorimetry: effect of triacylglycerol structure and its modification. Thermochim Acta. 395, 191-200. http:// dx.doi.org/10.1016/S0040-6031(02)00180-6

Akintayo ET. 2007. Ethylmethyldioxirane epoxidation of Plukenetia Cononophora oil. Bull. Chem. Soc. Ethiop. 21, 95-102.

Alam M, Akram D, Sharmin E, Zafar F, Ahmad S. 2014. Vegetable oil based eco-friendly coating materials: A review article. Arab. J. Chem. 7, 469-479. http://dx.doi. org/10.1016/j.arabjc.2013.12.023

Armstrong A, Ley SV. 1990. Total synthesis of Avermectin B1a: Planning of the synthesis and preparation of the C1-C10 "southern" hydrobenzofuran fragment. Synlett 1990, 323-325. http://dx.doi.org/10.1055/s-1990-21078

Biermann U, Bornscheuer U, Meier MAR, Metzger JO, Schäfer HJ. 2011. Oils and fats as renewable raw materials in chemistry. Angew. Chem. Int. Ed. Engl. 50, 3854-3871. http://dx.doi. org/10.1002/anie.201002767

Biermann U, Friedt W, Lang S, Lühs W, Machmüller G, Metzger JO, Rüsch M, Schäfer HJ, Schneider MP. 2000. New syntheses with oils and fats as renewable raw materials for the chemical industry. Angew. Chem. Int. Ed. 39, 2206-2224. http:// dx.doi.org/10.1002/9783527619849.ch25

Björkling F, Godtfredsen SE, Kirk O. 1990. Lipase-mediated formation of peroxycarboxylic acids used in catalytic epoxidation of alkenes. J. Chem. Soc., Chem. Commun. 1301-1303. http://dx.doi.org/10.1039/C39900001301

Borugadda VB, Goud VV. 2014. Epoxidation of castor oil fatty acid methyl esters (COFAME) as a lubricant base stock using heterogeneous ion-exchange resin (IR-120) as a catalyst. Energy Procedia 54, 75-84. http://dx.doi.org/10.1016/j. egypro.2014.07.249

Cai S, Wang L. 2011. Epoxidation of unsaturated fatty acid methyl esters in the presence of $\mathrm{SO}_{3} \mathrm{H}$-functional brønsted acidic ionic liquid as catalyst. Chinese J. Chem. Eng. 19, 57-63. http://dx.doi.org/10.1016/S1004-9541(09)60177-4

Campanella A, Rustoy E, Baldessari A, Baltanás MA. 2010. Lubricants from chemically modified vegetable oils. Bioresour. Technol. 101, 245-54. http://dx.doi.org/10.1016/j. biortech.2009.08.035

Choo, YM. 2014. Palm oil in the global oils and fats market, in: Palm Oil Familiriazation Programme (POFP) 2014. pp. $1-18$.

Cooney TI, Cardona F, Tran-Cong T. 2011. Kinetics of in situ epoxidation of hemp oil under heterogenous reaction conditions: An overview with preliminary results, in: Energy, Environment and Sustainability 2011. pp. 106-111.

Curci R, Fiorentino M, Serio MR. 1984. Asymmetric epoxidation of unfunctionalized alkenes by dioxirane intermediates generated from potassium peroxomonosulphate and chiral ketones. J. Chem. Soc., Chem. Commun. 1984, 155. http://dx.doi.org/10.1039/c39840000155

Curci R, Fiorentino M, Troisi L, Edwards JO, Pater RH. 1980. Epoxidation of alkenes by dioxirane intermediates generated in the reaction of potassium caroate with ketones. $J$. Org. Chem. 45, 4758-4760. http://dx.doi.org/10.1021/ jo01311a040

Dierker M, Schäfer HJ. 2010. Surfactants from oleic, erucic and petroselinic acid: Synthesis and properties. Eur. J. Lipid Sci. Technol. 112, 122-136. http://dx.doi.org/10.1002/ ejlt.200900126

Dinda S, Patwardhan AV, Goud VV, Pradhan NC. 2008. Epoxidation of cottonseed oil by aqueous hydrogen peroxide catalysed by liquid inorganic acids. Bioresour. Technol. 99, 3737-3744. http://dx.doi.org/10.1016/j. biortech.2007.07.015

Doll KM, Erhan SZ. 2008. Synthesis of cyclic acetals (ketals) from oleochemicals using a solvent free method. Green Chem. 10, 712-717. http://dx.doi.org/10.1039/B803513J

Feldmann G, Schäfer HJ. 2001. Fatty acids linked with dyes and corrosion inhibitors. Ol. Corps. Gras Lipides 8, 60-62. http://dx.doi.org/10.1051/ocl.2001.0060
Frohn M, Wang Z, Shi Y. 1998. A mild and efficient epoxidation of olefins using in situ generated dimethyldioxirane at high pH. J. Org. Chem. 63, 6425-6426. http://dx.doi. org/10.1021/jo980604+

Goud VV, Patwardhan AV, Dinda S, Pradhan NC. 2007. Epoxidation of karanja (Pongamia glabra) oil. Eur. J. Lipid Sci. Technol. 109, 575-584. http://dx.doi.org/10.1002/ ejlt. 200600298

Grausem B, Widemann E, Verdier G, Nosbüsch D, Aubert Y, Beisson F, Schreiber L, Franke R, Pinot F. 2014. CYP77A19 and CYP77A20 characterized from Solanum tuberosum oxidize fatty acids in vitro and partially restore the wild phenotype in an Arabidopsis thaliana cutin mutant. Plant. Cell Environ. 37, 2102-2115. http://dx.doi.org/10.1111/ pce. 12298

Greenspan FP, Gall RJ. 1953. Epoxy fatty acid ester plasticizers. Ind. Eng. Chem. 45, 2722.

Guidotti MN, Ravasio R, Psaro E, Gianotti S, Coluccia L, Marchese J. 2006. Epoxidation of unsaturated FAMEs obtained from vegetable source over Ti(VI)-grafted silica catalysts: A comparison between ordered and non-ordered mesoporous materials. J. Mol. Catalysis A: Chem. 250, 218-225.

Gunstone FD, Hamilton RJ. 2001. Oleochemical manufacture and applications. Sheffield Academic Press, Sheffield.

Hazimah AH, 2012. Palm oil: Going beyond basic oleochemicals, in: Palm Oil Trade Fair Seminar. pp. 1-54.

Hazimah AH, Tuan Ismail TNM, Hoong SS, Ooi TL, Ahmad S, Poo Palam KD, Cheong MY. 2011. Process to produce polyols. Patent no. US 7,932,409.

Hill K. 2000. Fats and oils as oleochemical raw materials. Pure Appl. Chem. 72, 1255-1264. http://dx.doi.org/10.1351/ pac200072071255

Hoong SS, Mohd Norhisham S, Tuan Noor Maznee TI, Kosheela D, Nurul'Ain H, Hazimah AH, Ooi TL, Salmiah A. 2008. Preparation of a low viscosity and light coloured fatty acid-based polyol. J. Oil Palm Res. 2008, 44-52

Höfer R. 1999. Oleochemical polyols - New Materials for Polyurethane Applications, in: European Coatings Conference. Berlin.

Kandula S, Stolp L, Grass M, Woldt B, Kodali D. 2014. Synthesis and functional evaluation of soy fatty acid methyl ester ketals as bioplasticizers. J. Am. Oil Chem. Soc. 91, 1967-1974. http://dx.doi.org/10.1007/ s11746-014-2529-8

Klement I, Liitjens H, Knochel P. 1997. Transition metal catalyzed oxidations in perfluorinated solvents. Angew. Chem. Int. Ed. 36, 1454-1456. http://dx.doi.org/10.1002/ anie. 199714541

Köckritz A, Martin A. 2008. Oxidation of unsaturated fatty acid derivatives and vegetable oils. Eur. J. Lipid Sci. Technol. 110, 812-824. http://dx.doi.org/10.1002/ejlt.200800042

Kreienfeld G, Stoll G. 1997. Alkyl polyglycosides: Technology, Properties and Applications. VCH Publishers.

Lee PL, Wan Yunus WMZ, Yeong SK, Abdullah DK, Lim WH. 2009. Optimization of the epoxidation of methyl ester of palm fatty acid distillate. J. Oil Palm Res. 21, 675-682.

Li LH, Wang D. 1997. Asymmetric epoxidation of nearly symmetrical cis-alkenes. Sharpless epoxidation of (1,2-dialkyl) vinylsilanols. Tetrahedron Lett. 38, 101-104. http://dx.doi. org/10.1016/S0040-4039(96)02226-5

Messeguer A, Sanchez-Baeza F, Casas J, Hammock BD. 1991. Use of dimethyldioxirane in the preparation of epoxy derivatives related to insect juvenile hormones. Tetrahedron 47, 1291-1302.

Mohd Nor H, Mahmood MH, Kifli H, Abdul Rahman M. 1992. The use of epoxidized palm oil products for the synthesis of radiation curable resins. J. Palm Oil Res. 4, 60-64.

Moser BR, Sharma BK, Doll KM, Erhan SZ. 2007. Diesters from oleic acid: Synthesis, low temperature properties, and oxidation Stability. J. Am. Oil Chem. Soc. 84, 675-680. http://dx.doi.org/10.1007/s11746-007-1083-z

Mungroo R, Pradhan NC, Goud VV, Dalai, AK. 2008. Epoxidation of canola oil with hydrogen peroxide catalyzed by acidic ion exchange resin. J. Am. Oil Chem. Soc. 85, 887-896. http://dx.doi.org/10.1007/s11746-008-1277-z 
Musa JJ. 2009. Evaluation of the lubricating properties of palm kernel oil. Leonardo Electron. J. Pract. Technol. 14, 107-114.

Ni MFF, Salimon J. 2012. Epoxidation of palm kernel oil fatty acids. J. Sci. Technol. 4, 87-98.

Nicolet BH, Poulter, TC. 1930. Epoxy acids from oleic and elaidic acids. J. Am. Chem. Soc. 52, 1186-1191.

Norhayati MN, Tuan Noor Maznee TI, Yeong SK, Hazimah AH. 2013. Synthesis of palm-based polyols: Effect of K10 montmorillonite catalyst. J. Oil Palm Res. 25, 92-99.

Nowak JA, Zilner TA, Mullin, LP. 2003. In situ formation of peracid from organic acid and oxidizing agent. Patent no. US 6740763 B1.

Omar MN, Moynihan HA, Hamilton RH. 2003. Asymmetric Sharpless epoxidation of 13S-hydroxy-9Z-. 11E-octadecadienoic acid (13S-HODE). Eur. J. Lipid Sci. Technol.105,43-44.http://dx.doi.org/10.1002/ejlt.200390005

Oliw EH. 1994. Oxygenation of polyunsaturated fatty acids by Cytochrome P450 Monooxygenases. Prog. Lipid Res. 33, 329-354. http://dx.doi.org/10.1016/0163-7827(94)90029-9

Orellana-Coca C, Billakanti JM, Mattiason B, Hatti-Kaul R. 2007. Lipase mediated simultaneous esterification and epoxidation of oleic acid for the production of alkylepoxystearates. J. Mol. Catalysis B: Enzymatic 44, 133-137. http://dx.doi.org/10.1016/j.molcatb.2006.09.002

Piazza GJ. 1999. Some recent advances in epoxide synthesis, in: Knothe G, Derksen, JTP. (Eds.), Recent Developments in the Synthesis of Fatty Acid Derivatives. AOCS Press, p. 250. http://dx.doi.org/10.1201/9781439832073.ch11

Piazza GJ, Foglia TA. 2005. Preparation of fatty amide polyols via epoxidation of vegetable oil amides by oat seed peroxygenase. J. Am. Oil Chem. Soc. 82, 481-485. http://dx.doi. org/10.1007/s11746-005-1097-y

Piazza GJ, Foglia TA, Nuñez A. 2001. Optimizing reaction parameters for the enzymatic synthesis of epoxidized oleic acid with oat seed peroxygenase. J. Am. Oil Chem. Soc. 78, 589-592. http://dx.doi.org/10.1007/s11746-001-0309-9

Ragagnin G, Knochel P. 2004. Aerobic Ru-catalyzed epoxidations in fluorous biphasic system using new fluorous benzimidazolic ligands. Synlett 2004, 951-954. http://dx.doi. org/10.1055/s-2004-820042

Rahman RA, Sadi S. 1998. Hydroxystearic compounds from unsaturated palm fatty acid. J. Oil Palm Res. 10, 1-14.

Richtler HJ, Knaut J. 1984. Challenges to a mature industry: Marketing and economics of oleochemicals in Western Europe. J. Am. Oil Chem. Soc. 61, 160-175.
Rios LA, Weckes PP, Schuster H, Hölderich WF. 2005. Mesoporous and amorphous Ti-silicas on the epoxidation of vegetable oils. J. Catal. 232, 19-26. https://doi. org/10.1016/j.jcat.2005.02.011

Rupilius W, Ahmad S. 2007. Palm oil and palm kernel oil as raw materials for basic oleochemicals and biodiesel. Eur. $J$. Lipid Sci. Technol. 109, 433-439. http://dx.doi.org/10.1002/ ejlt.200600291

Saithai P, Lecomete J, Dubreucq E, Tanrattanakul, V. 2013. Effects of different epoxidation methods of soybean oil on the characteristics of acrylated epoxidized soybean oil-co-poly(methyl methacrylate) copolymer. eXPRESS Polym. Lett, 7, 910-924.

Saurabh T, Patnaik M, Bhagt SL, Renge VC. 2011. Epoxidation of vegetable oils: A review. Int. J. Adv. Eng. Technol. II, 491-501.

Shaari NZK, Lye OT, Ahmad S. 2006. Production of moulded palm-based flexible polyurethane foams. J. Oil Palm Res. 18, 198-203.

Sonnet PE, Foglia TA. 1996. Epoxidation of natural triglycerides with ethylmethyldioxirane. J. Am. Oil Chem. Soc. 73, 461-464. http://dx.doi.org/10.1007/BF02523919

Sun S, Ke X, Cui L, Yang G, Bi Y, Song F, Xu X. 2011. Enzymatic epoxidation of Sapindus mukorossi seed oil by perstearic acid optimized using response surface methodology. Ind Crops Prod. 33, 676-682. http://dx.doi.org/10.1016/j. indcrop.2011.01.002

Swern D. 1955. Oxygenated fatty acids. Prog. Chem. Fats Other Lipids 3, 213-239.

Vlček T, Petrović ZS. 2006. Optimization of the chemoenzymatic epoxidation of soybean oil. $\mathrm{J} . \mathrm{Am}$. Oil Chem. Soc. 83, 247-252. http://dx.doi.org/10.1007/ s11746-006-1200-4

Zhang G, Kodani S, Hammock BD. 2014. Stabilized epoxygenated fatty acids regulate inflammation, pain, angiogenesis and cancer. Prog. Lipid Res. 53, 108-23. http://dx.doi. org/10.1016/j.plipres.2013.11.003

Zhang W, Jiang P, Wu J, Zhang P, Jiang K. 2014. Catalytic epoxidation of fatty acid methyl esters by modified metalloporphyrins with variable metals and electron-donating substituents. Reac. Kinet. Mech. Cat. 112, 147-158. http:// dx.doi.org/10.1007/s11144-014-0676-4

WWW Document, 2011. About Palm Oil. Malaysian Palm Oil Board. Available at: http://www.palmoilworld.org/about_ palmoil.html. Accessed 28 Sept. 2016]. 